\title{
有限要素解析におけるソース項の保存型離散化* (六面体要素の場合)
}

邵 長城 ${ }^{* 1}$ ，飯沼 敏也 ${ }^{* 1}$

\section{Conservative Discretization of the Source Term in Finite Element Analyses (In the Case of Hexahedral Elements)}

\author{
Changcheng SHAO*1 and Toshiya IINUMA \\ ${ }^{* 1}$ AW Engineering Co., Ltd. \\ No.48-8 Kitaawarashimo, Sakurai-Cho, Anjo, Aichi, 444-1154 Japan
}

\begin{abstract}
The conventional Galerkin finite element solution is mesh dependent, and its discretization for Poisson's equation can not satisfy the conservation law at a nodal level when unstructured linear meshes are used. This research tries to solve these problems by introducing a new concept of the virtual nodal domain(Vnd) for a linear hexahedral element, and distributing the source term to a nodal algebraic equation in proportion to the volume of the Vnd. The Vnd is evaluated using a second-order flux existing within a linear element. We proved that the total Vnd of the eight nodes equals to the volume of the element, which guarantees that our scheme is also elementally conservative. Numerical simulation of heat conduction with both Dirichlet and Neumann boundary conditions shows that the accuracy has been improved obviously comparing with the conventional Galerkin FEM for unstructured hexahedral meshes, especially for bad quality elements. Our scheme can be introduced into any commercial FEM code quite easily.
\end{abstract}

Key Words : Finite Element Method, Conservative Discretization, Source Term, Poisson's Equation, Hexahedral Element, Virtual Nodal Domain(Vnd), Computational Method, Numerical Analysis

\section{1. 緒言}

有限要素法は, 誤差の評価が明瞭で汎用性に富むなどの特徴があって ${ }^{(1)}(3)$, 最も広く使用される数值解法の 一つになっている. しかし，昔から指摘されてきたメッシュ・パターン，そして要素形状によって解析結果が 変るといったメッシュ依存性問題 ${ }^{(1)(4)}$ が, 依然として解決されていない. たとえば, Poissonの方程式に適用した 場合には, 各節点の代数方程式に分配されるソース量が要素形状に対応しきれず, 二階微分項の離散化との整 合性が取れないことがある. Taylor展開の観点から有限要素法について考察したKurtze ${ }^{(5)}$ が，メッシュ節点の不 規則な配置により, 離散化方程式がもはや元の微分方程式の近似ではなくなり, 有限要素解が局所領域におい て微分方程式の解に収束しないこともあると指摘した。この現象は, 微分方程式の階数より低い次数の局所多 項式で未知関数を近似する際に発生する.

六面体要素については，有限要素法の関数近似を用いて，節点を囲う局所領域に保存則を適用して離散化を 行う手法が提案された ${ }^{(6)}$ (7). 局所領域とは, 要素の辺の中点, 面上の四節点の中心と要素の八節点の中心を頂点 としたものである。この手法では局所領域からの出入りの計算が一次精度のままであり，メッシュ依存性の改 善効果は示されていない. 現状の実用解析では，多大な労力を費やしてメッシュの品質を維持させる方法が主 流となっている.

$\operatorname{Iwaki}^{(8)}, \mathrm{Urata}^{(9)}$, and Kanayama ${ }^{(10)}$ の研究では，定常移流拡散方程式の拡散項をGalerkin法により 鋭角線形三角 形要素において離散化した結果を, 要素辺の中点から外心までの線分を通過して流出した物質量と解釈し, 中

* 原稿受付 2011 年 10 月 23 日

*1 正員, (株)エィ・ダブリュ・エンジニアリング＼cjkstart技術開発部

( ( $444-1154$ 愛知県安城市桜井町北阿原下 48-8 番地)

E-mail: i74160_shao@aisin-aw.co.jp 
点と外心を繋ぐ線で閉じた領域にCircumcentric Domainと名づけた．著者らは，鈍角も含めた線形三角形要素に ついて, 中点に存在する二次精度の流束と中点から外心までの線分を利用して要素形状に応じたソース項の分 配方法を提案した ${ }^{(1)}$. 外心が存在しない四辺形要素 ${ }^{(12)}$ について, また, 外心を利用すると弊害が生じる四面体 要素 ${ }^{(13)}$ について, 仮想節点領域の概念とそれを基準としたソース項の分配方法を提案し，メッシュ依存性問題 の解消効果と低品質要素での精度向上効果が得られた.

本稿では，保存則の観点から提案された仮想節点領域の概念とそれを基準としたソース項の分配方法を，線 形六面体要素を用いた Poisson の方程式の離散化に展開し, 品質が低い要素形状からも高精度な数值解が得られ るスキームの開発を目的とする. Galerkin 法による六面体要素での離散化においては, 四面体と異なって, ソー ス項の節点への分配がヤコビ行列により要素形状に応じてある程度自動的に調整されている. そのため, より 高精度なスキームの開発は一層難しくなると考えられる.

\section{2. 従来のソース項離散化の問題点}

\section{$2 \cdot 1$ 保存則による考察}

三次元 Poisson の方程式は次式になる.

$$
-\frac{\partial}{\partial x}\left(\lambda \frac{\partial T}{\partial x}\right)-\frac{\partial}{\partial y}\left(\lambda \frac{\partial T}{\partial y}\right)-\frac{\partial}{\partial z}\left(\lambda \frac{\partial T}{\partial z}\right)=Q
$$

ここで, $T$ : 温度, $Q$ : ソース項, $\lambda$ : 熱伝導率, である. 式(1)に Galerkin 有限要素法を適用すると, 対象節 点 $P$ についての積分式として次式が得られる.

$$
-\sum_{e} \iiint_{e} W_{P}\left[\frac{\partial}{\partial x}\left(\lambda \frac{\partial T}{\partial x}\right)+\frac{\partial}{\partial y}\left(\lambda \frac{\partial T}{\partial y}\right)+\frac{\partial}{\partial z}\left(\lambda \frac{\partial T}{\partial z}\right)\right] d x d y d z=\sum_{e} \iiint_{e} W_{P} Q d x d y d z
$$

ここで, $e$ は対象節点周りの要素であり, $\Sigma$ は各要素での演算の和を意味し, $W_{P}$ は Galerkin 重み関数である. 左辺に対して，部分積分とガウス・グリーンの定理を適用すると，式(2)は式(3)になる.

$$
\sum_{e} \iiint_{e} \lambda\left(\frac{\partial W_{P}}{\partial x} \frac{\partial T}{\partial x}+\frac{\partial W_{P}}{\partial y} \frac{\partial T}{\partial y}+\frac{\partial W_{P}}{\partial z} \frac{\partial T}{\partial z}\right) d x d y d z=\sum_{e} \iiint_{e} W_{P} Q d x d y d z
$$

ここで, 簡単化のため式(2)左辺の積分から出た自然境界での積分を節 3.1 の終了まで議論の対象外とする. 式 (3)を線形六面体要素に適用した結果について, 保存則の観点から考察する. すなわち, ある領域内部の熱発生 量と, 同じ領域の境界面（検査面と称寸る）上での出入りによる熱の流失量とが等しいかについて調べる，こ の際，各量はできるだけ高い精度で評価されることが望まれる.

\section{$2 \cdot 1 \cdot 1$ 長方体要素}

要素内の温度分布を多項式により近似し, 要素e を図 1 の長方体要素に当てはめると, 式(3)左辺の要素積分 は次式となる．ただし，対象節点 $P$ の要素における局所番号を 1 とした.

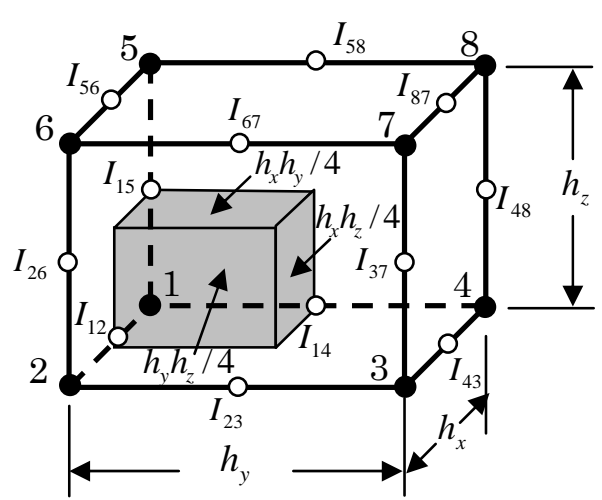

Fig. 1 Integration in a rectangular-prism element 


$$
\begin{aligned}
\iiint_{e} \lambda\left(\frac{\partial W_{P}}{\partial x} \frac{\partial T}{\partial x}+\frac{\partial W_{P}}{\partial y} \frac{\partial T}{\partial y}+\frac{\partial W_{P}}{\partial z} \frac{\partial T}{\partial z}\right) d x d y d z= & \frac{h_{y} h_{z}}{4} \times \lambda\left[\frac{4}{9} \frac{T_{1}-T_{2}}{h_{x}}+\frac{2}{9} \frac{T_{4}-T_{3}}{h_{x}}+\frac{2}{9} \frac{T_{5}-T_{6}}{h_{x}}+\frac{1}{9} \frac{T_{8}-T_{7}}{h_{x}}\right] \\
& +\frac{h_{x} h_{z}}{4} \times \lambda\left[\frac{4}{9} \frac{T_{1}-T_{4}}{h_{y}}+\frac{2}{9} \frac{T_{2}-T_{3}}{h_{y}}+\frac{2}{9} \frac{T_{5}-T_{8}}{h_{y}}+\frac{1}{9} \frac{T_{6}-T_{7}}{h_{y}}\right] \\
& +\frac{h_{x} h_{y}}{4} \times \lambda\left[\frac{4}{9} \frac{T_{1}-T_{5}}{h_{z}}+\frac{2}{9} \frac{T_{2}-T_{6}}{h_{z}}+\frac{2}{9} \frac{T_{4}-T_{8}}{h_{z}}+\frac{1}{9} \frac{T_{3}-T_{7}}{h_{z}}\right]
\end{aligned}
$$

節点 $i$ と $j$ を結ぶ線分の中点を点 $I_{i j}$ で, 両節点間の距離を $h_{i j}$ で表わすと, $\lambda\left(T_{i}-T_{j}\right) / h_{i j}$ は点 $I_{i j}$ での節点 $i$ から 節点 $j$ に向から二次精度の熱流束であることが分かる. すなわち，式(4)右辺の 1 項目は，点 $I_{12}$ での節点 1 から 2 に向から二次精度の熱流束, 点 $I_{43}$ での節点 4 から 3 に向かう二次精度の熱流束, 点 $I_{56}$ での節点 5 から 6 に向 かう二次精度の熱流束と点 $I_{87}$ での節点 8 から 7 に向かう二次精度の熱流束の重み付き平均により, 面積 $h_{y} h_{z} / 4$ を通過する熱量である．流束の通過面積 $h_{y} h_{z} / 4$ は流束に垂直で中点 $I_{12}$ を通るものである. 同様に，2項目か ら，節点 1 から節点 4 に向から熱流束に垂直で中点 $I_{14}$ を通る通過面積 $h_{x} h_{z} / 4$ が得られる. また， 3 項目から， 節点 1 から節点 5 に向から熱流束に垂直で中点 $I_{15}$ を通る通過面積 $h_{x} h_{y} / 4$ が得られる. これらの通過面を検査 面として考え，検査面と要素表面が囲う領域は図 1 に示す辺長が $h_{x} / 2, h_{y} / 2, h_{z} / 2$ の長方体となる.

一方, $Q$ が要素内で定数の場合には, 式(3)右辺の要素積分は次式になる.

$$
\iiint_{e} W_{P} Q d x d y d z=\frac{V}{8} Q
$$

ここで， $V$ は要素体積である.すなわち，節点 1 に寄与された熱量は $V / 8$ の体積から発生したものである. 検 査面が囲う体積とソース項の体積とが一致するため，二次精度の流束により評価された熱の流失量と熱の発生 量とが等しくなっている（このことを“保存則を二次精度で満たす”により表現する）。要素形状の対称性を考 えると，ほかの七節点でも保存則を二次精度で満たすことが分かる。

\section{$2 \cdot 1 \cdot 2$ 平行四辺形を押し出した柱要素}

図 2(a)のような $y z$ 平面上にある平行四辺形を $x$ 方向に幅 $h_{x}$ 押し出した六面体要素において, 対象節点を 4 と すると, 式(3)左辺の要素積分は次式になる.

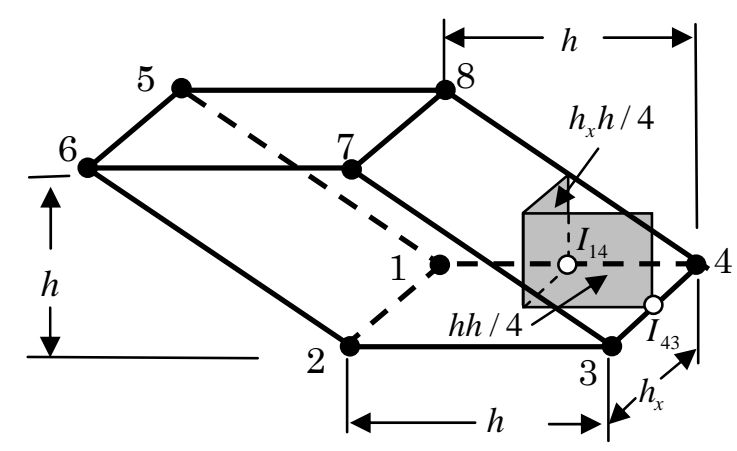

(a) Node 4

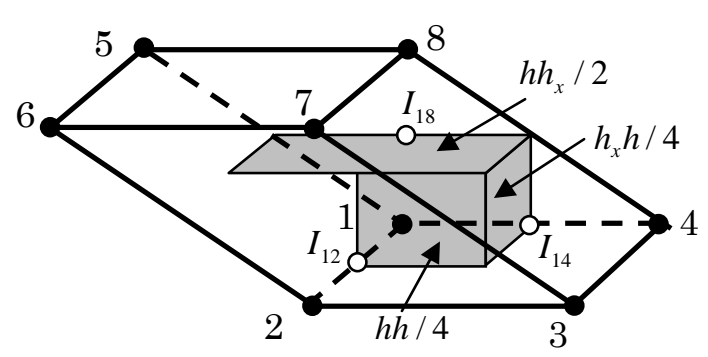

(b) Node 1

Fig. 2 Integration in a parallelogram-prism element

$$
\begin{aligned}
& \iiint_{e} \lambda\left(\frac{\partial W_{P}}{\partial x} \frac{\partial T}{\partial x}+\frac{\partial W_{P}}{\partial y} \frac{\partial T}{\partial y}+\frac{\partial W_{P}}{\partial z} \frac{\partial T}{\partial z}\right) d x d y d z \\
= & \frac{h h}{4} \times \lambda\left[\frac{4}{9} \frac{T_{4}-T_{3}}{h_{x}}+\frac{2}{9} \frac{T_{1}-T_{2}}{h_{x}}+\frac{2}{9} \frac{T_{8}-T_{7}}{h_{x}}+\frac{1}{9} \frac{T_{5}-T_{6}}{h_{x}}\right]+\frac{h_{x} h}{4} \times \lambda\left[\frac{2}{3} \frac{T_{4}-T_{1}}{h}+\frac{1}{3} \frac{T_{3}-T_{2}}{h}\right]
\end{aligned}
$$


式(6)右辺の各項は, 二次精度の熱流束により, それぞれ中点 $I_{43}$ を通る広さが $h^{2} / 4$ の面積を, 中点 $I_{14}$ を通る 広さが $h_{x} h / 4$ の面積を, 通過する熱量である. ここでの $h^{2} / 4$ の面積と $h_{x} h / 4$ の面積は, それぞれ節点 4 から 3 に向から流束に，節点 4 から 1 に向かう流束に垂直である.

なお, 対象節点を同要素の節点 1 とすると, 式(3)左辺の要素積分は次式になり, 図 $2(b)$ に示すそれぞれ中点 $I_{12}, I_{14}$ と $I_{18}$ を通る広さが $h^{2} / 4, h_{x} h / 4$ と $h_{x} h / 2$ の通過面が得られる.

$$
\begin{aligned}
& \iiint_{e} \lambda\left(\frac{\partial W_{P}}{\partial x} \frac{\partial T}{\partial x}+\frac{\partial W_{P}}{\partial y} \frac{\partial T}{\partial y}+\frac{\partial W_{P}}{\partial z} \frac{\partial T}{\partial z}\right) d x d y d z \\
= & \frac{h h}{4} \times \lambda\left[\frac{4}{9} \frac{T_{1}-T_{2}}{h_{x}}+\frac{2}{9} \frac{T_{4}-T_{3}}{h_{x}}+\frac{2}{9} \frac{T_{5}-T_{6}}{h_{x}}+\frac{1}{9} \frac{T_{8}-T_{7}}{h_{x}}\right] \\
& +\frac{h_{x} h}{4} \times \lambda\left[\frac{2}{3} \frac{T_{1}-T_{4}}{h}+\frac{1}{3} \frac{T_{2}-T_{3}}{h}\right]+\frac{h_{x} h}{2} \times \lambda\left[\frac{2}{3} \frac{T_{1}-T_{8}}{h}+\frac{1}{3} \frac{T_{2}-T_{7}}{h}\right]
\end{aligned}
$$

図 2 より, 節点 4 と 1 とでは, 熱流束の通過面積が異なることが分かる. Q が要素内で定数の場合には, 式 (3)右辺の要素積分により両節点に寄与された熱量が同じで, $V / 8$ から発生したものである. 従って, この要素 では二次精度の意味で保存則が満たされていない。

このような二次精度で保存則が満たされない問題は, ほかの要素にも存在する.

\section{$2 \cdot 2$ 収束性についての考察}

式(3)を 16 個の図 2 の要素に囲まれる図 3 の中心節点に適用して, 得られた代数方程式を Taylor 展開により整 理し $O\left(h^{2}\right)$ の項を省略すると次式になる.

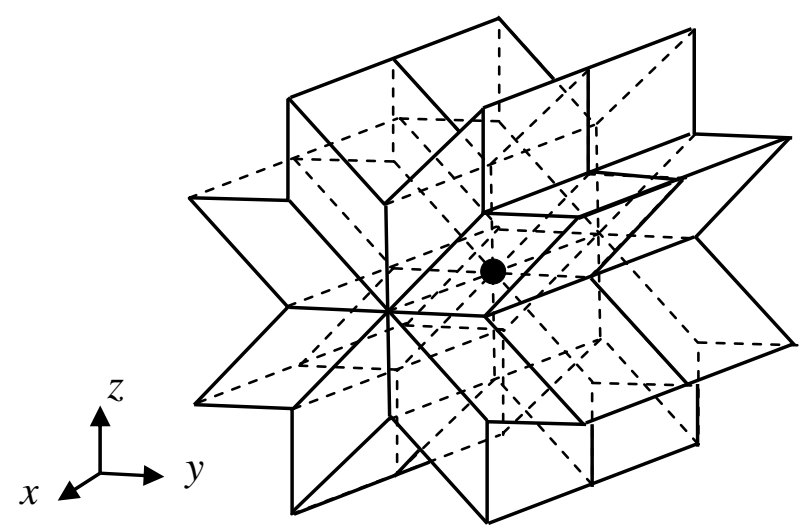

Fig. 3 Central node and local parallelogram-prism mesh

$$
-V \lambda\left(2 \times \frac{\partial^{2} T}{\partial x^{2}}+\frac{\partial^{2} T}{\partial y^{2}}+\frac{\partial^{2} T}{\partial z^{2}}\right)=2 \times V Q
$$

ここで，ソース項を定数とした. 式(8)は元の微分方程式に帰着しないことが分かる.

このような離散化が微分方程式に収束しない局所メッシュは, ほかにも存在する.

\section{3. ソース項の保存型離散化 (CSFE)}

本章では, 節 2.1 で議論された歪んだ要素に存在する, 保存則が節点周辺領域において満たされない問題を 解決するスキームを考案し，このスキームについて微分方程式への収束性などの理論検証を行う. 


\section{$3 \cdot 1$ 仮想節点領域(Virtual Nodal Domain, Vnd)}

任意形状の六面体要素に対して, 対象節点の要素 $e$ における節点番号を 1 とすると, 式(3)左辺の要素積分は 次式で表わすことができる.

$$
\iiint_{e} \lambda\left(\frac{\partial W_{P}}{\partial x} \frac{\partial T}{\partial x}+\frac{\partial W_{P}}{\partial y} \frac{\partial T}{\partial y}+\frac{\partial W_{P}}{\partial z} \frac{\partial T}{\partial z}\right) d x d y d z=\lambda \sum_{i=1}^{8} A_{1 i} T_{i}
$$

係数 $A_{1 i}(i=1,2, \ldots, 8)$ は八節点の座標のみに依存する定数である. 有限要素法の性質より, 次式が成り立つ.

$$
A_{11}=-\sum_{i=2}^{8} A_{1 i}
$$

式(10)を利用すると式(9)の右辺を次式のような定数と熱流束との掛け算の形に書き換えることができる.

$$
\iiint_{e} \lambda\left(\frac{\partial W_{P}}{\partial x} \frac{\partial T}{\partial x}+\frac{\partial W_{P}}{\partial y} \frac{\partial T}{\partial y}+\frac{\partial W_{P}}{\partial z} \frac{\partial T}{\partial z}\right) d x d y d z=\sum_{i=2}^{8}\left(-A_{1 i} L_{1 i}\right) \times \lambda \frac{T_{1}-T_{i}}{L_{1 i}}
$$

ここで, $L_{1 i}\left(=\left[\left(x_{i}-x_{1}\right)^{2}+\left(y_{i}-y_{1}\right)^{2}+\left(z_{i}-z_{1}\right)^{2}\right]^{1 / 2}\right)$ は節点 1 と節点 $i$ 間の距離である. 式(11)の右辺は, 節点 1 と $i$ を結ぶ線分の中点 $I_{1 i}$ での節点 1 から節点 $i$ に向かう二次精度の熱流束により, 流束に垂直で点 $I_{1 i}$ を通る面 積 $\left(-A_{1 i} L_{1 i}\right)$ を通過する熱量である. 保存則の観点から考えると, この熱の流出量に対して節点 1 に寄与すべき 熱源の発生体積は, 図 4 に示寸中点 $I_{1 i}$ を通る広さ $\left(-A_{1 i} L_{1 i}\right)$ の面積を底面とし, 節点 1 と $I_{1 i}$ との距離 $L_{1 i} / 2$ を高 さとした錐体の体積となる。この体積をVnd ${ }_{1 i}$ で表わすと, 次式により算出される.

$$
\operatorname{Vnd}_{1 i}=\frac{1}{6}\left(-A_{1 i}\right) L_{1 i}^{2}
$$

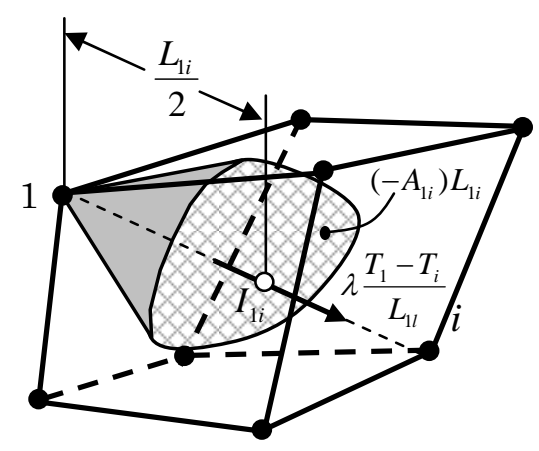

Fig. 4 Image of Virtual Node Domain $V_{n d}$

式(11)の七つの熱流束に対して, 節点 1 に寄与すべき熱源の発生体積の和をVnd ${ }_{1}$ で表わすと, 次式が得られ る.

$$
V n d_{1}=\sum_{i=2}^{8} V n d_{1 i}
$$

Vnd ${ }_{1}$ を節点 1 の仮想節点領域(Virtual Nodal Domain)と称する. しかし, 長方体以外の要素では, この七つの流 束の通過面は，必ずしも繋いだ面を形成しない，したがって，通過面積の広さは定義できるが，形状の定義は できない，その結果，仮想節点領域は体積の定義はできるが，形状の定義はできない，この意味で，図 4 は, 仮想節点領域の体積を示寸ものではあるが，その形状を示すものではない.

同じ方法で，ほかの節点の仮想節点領域を算出することもできる．また，要素形状によって熱流束の係数が 負になることもあるが，対象節点に向かう流入熱流束であるため，それがもたらす仮想節点領域は負になる.

\section{$3 \cdot 2 \operatorname{CSFE}$ の提案}

保存則の観点から, 仮想節点領域からの発熱量だけを式(3)の右辺に寄与すべきである. しかし, 仮想節点領 
域には形状の定義ができないため，それを部分領域法のように積分範囲とすることができない．そこで，ソー ス項が定数の場合において $\iint_{e} W_{P} d x d y d z の$ 体積からの発熱量となる式(3)右辺の $\iiint_{e} W_{P} Q d x d y d z に$, $\left(V_{n} d_{P}-\iiint_{e} W_{P} d x d y d z\right)$ の体積からの発熱量を加える. 寸なわち, 式(2)の右辺に $\left(V n d_{P}-\iiint_{e} W_{P} d x d y d z\right) Q_{0}$ を加えた次 式を提案する.

$$
-\sum_{e} \iiint_{e} W_{P}\left[\frac{\partial}{\partial x}\left(\lambda \frac{\partial T}{\partial x}\right)+\frac{\partial}{\partial y}\left(\lambda \frac{\partial T}{\partial y}\right)+\frac{\partial}{\partial z}\left(\lambda \frac{\partial T}{\partial z}\right)\right] d x d y d z=\sum_{e}\left[\iiint_{e} W_{P} Q d x d y d z+\left(V n d_{P}-\iiint_{e} W_{P} d x d y d z\right) Q_{O}\right]
$$

ここで, $\left(V n d_{P}-\iiint_{e} W_{P} d x d y d z\right) Q_{o}$ は調整項と呼び, $Q_{O}$ は要素節点の平均位置でのソース值であり積分点でのソ 一ス值と同じ方法で算出する. 調整項の導入により, 要素形状に応じたソース量が節点方程式に分配されるよ うになり，メッシュ依存性の改善効果や，低品質要素での精度向上が期待できる．また，ソース項が定数の場 合には，二次精度で評価された熱の流出量と寄与された発熱量とが等しくなる．すなわち，保存則が節点レベ ルにおいて二次精度で満たされる. 本提案が, 式(2)左辺の積分から得られた式(3)の左辺を基準としたもので あるため，境界積分はゼロではない場合には，Galerkin 法と同様な形で式(14)に現れる.

調整項の計算に当たっては, Galerkin 法により算出された $A_{i j}$ や, ヤコビ行列などを流用できる. また, 左辺 のマトリックスも変っていないため，全体の計算量は Galerkin 法と殆ど変らないと考えられる.

\section{$3 \cdot 3$ CSFE についての理論検証}

誤差評価理論により 全領域平均の意味での最良近似として評価されたGalerkin有限要素法 ${ }^{(3)}$ に対して, CSFEで は節点での関数值に注目し, 線形要素に点在する二次精度の流束を活用したソース項の新しい分配方法により, 節点関数值の誤差を低減する。 また, 線形要素から得られたGalerkin有限要素解, およびその一階微分における 誤差のルート 2 乗平均は, それぞれ $h^{2}\|Q\|$ と $h\|Q\|$ により評価することができる(3).ここでの $\|Q\|$ はソース項のル 一ト 2 乗平均である. それに合わせるように, 式(14)右辺の調整項によるGalerkin法への修正量は $Q$ の大きさに 比例している.ゆえに, 調整項の導入は誤差評価理論と矛盾しない.

\section{$3 \cdot 3 \cdot 1$ 整合性}

保存則の観点から定義された仮想節点領域と, 検查面の囲う体積とが等しい場合は, 整合性が満たされてい るという。ここで, 検査面の囲う体積が定義された長方体要素について整合性の確認を行う. 式(4)を次式に書 き換えることができる.

$$
\begin{aligned}
\iiint_{e} \lambda\left(\frac{\partial W_{P}}{\partial x} \frac{\partial T}{\partial x}+\frac{\partial W_{P}}{\partial y} \frac{\partial T}{\partial y}+\frac{\partial W_{P}}{\partial z} \frac{\partial T}{\partial z}\right) d x d y d z= & \lambda\left[4(\alpha+\beta+\gamma) T_{1}+(-4 \alpha+2 \beta+2 \gamma) T_{2}+(-2 \alpha-2 \beta+\gamma) T_{3}\right. \\
& +(2 \alpha-4 \beta+2 \gamma) T_{4}+(2 \alpha+2 \beta-4 \gamma) T_{5}+(-2 \alpha+\beta-2 \gamma) T_{6} \\
& \left.+(-\alpha-\beta-\gamma) T_{7}+(\alpha-2 \beta-2 \gamma) T_{8}\right]
\end{aligned}
$$

ここで， $\alpha=h_{y} h_{z} /\left(36 h_{x}\right), \quad \beta=h_{x} h_{z} /\left(36 h_{y}\right), \gamma=h_{x} h_{y} /\left(36 h_{z}\right)$ である. 式(12), (13)と式(15)右辺の各定数により 求められた仮想節点領域は次式となる.

$$
\operatorname{Vnd}_{1}=\frac{V}{8}
$$

図 1 に示す検査面が囲う体積と比較すると, 整合性が取れていることが確認できる. 要素形状の対称性を考慮 すると，ほかの七節点についても同じ結論が得られる．また， $\iiint_{e} W_{P} d x d y d z=V / 8$ となるため, 式(14)における調 整項がゼロとなる. 寸なわち, 長方形要素の場合には, 保存型離散化は Galerkin 有限要素法と同じものになる.

\section{$3 \cdot 3 \cdot 2$ 正規性}

正規性とは, 次式が成立すること, すなわち, 一要素における八節点の調整項の合計がゼロになることを指 す. 


$$
\frac{\sum_{i=1}^{8} V n d_{i}}{V}=1
$$

任意形状の六面体要素において, 正規性は満たされることが理論的に証明された (付録を参照).正規性により， 保存型離散化は要素ごとに保存則を満たすことが保証される.

\section{$3 \cdot 3 \cdot 3$ 収束性}

ソース項が定数の場合, 一要素から式(14)右辺への寄与は次式となる.

$$
\iiint_{e} W_{P} Q d x d y d z+\left(V n d_{P}-\iiint_{e} W_{P} d x d y d z\right) Q_{O}=V n d_{P} \times Q
$$

図 2 (a)の節点 4 について $V n d_{p}=\left(h^{2} / 4\right) \times\left(h_{x} / 6\right)+\left(h h_{x} / 4\right) \times(h / 6)=V / 12$ となるため, 式(14)を図 3 の局所メッシュ に適用寸ると，右辺は16×(V/12)Qになる. 寸なわち，式(8)の代わりに次式が得られる.

$$
-V \lambda\left(\frac{6}{3} \times \frac{\partial^{2} T}{\partial x^{2}}+\frac{3}{3} \times \frac{\partial^{2} T}{\partial y^{2}}+\frac{3}{3} \times \frac{\partial^{2} T}{\partial z^{2}}\right)=\frac{4}{3} \times V Q
$$

式(19)は, 調整項の導入により $x, y, z$ 三方向の平均の意味で Poisson の方程式に収束するようになってい る，収束性についての検討は，メッシュ幅をゼロに近づかせる条件下でのものであるため，その結論は，ソー ス項が定数ではない場合にも成立する. また，この検討結果は，一般形状の要素からなす局所メッシュに対し ても，調整項の導入により微分方程式への収束性が改善されることを示唆する.

\section{4. 数值解析事例}

\section{$4 \cdot 1$ 解析問題とメッシュ}

保存型離散化の精度改善効果を三つの熱伝導問題の解析事例により示す。この際，解析領域を立方体領域 $(0 \leq x, y, z \leq 1)$ とし,$\lambda=1$ とした.

解析問題 1 としては, 式(20)の定数のソース項に式(21)の基本境界条件と式(22)の自然境界条件を加えたもの を取り上げた。

$$
\begin{gathered}
Q=8 \\
T=1-\frac{4}{3}\left[0.5^{2}+(y-0.5)^{2}+(z-0.5)^{2}\right] \quad(x=0), \\
T=1-\frac{4}{3}\left[(x-0.5)^{2}+0.5^{2}+(z-0.5)^{2}\right] \quad(y=0), \\
T=1-\frac{4}{3}\left[(x-0.5)^{2}+(y-0.5)^{2}+0.5^{2}\right] \quad(z=0) \\
\frac{\partial T}{\partial n}=-\frac{4}{3} \quad(x=1, \text { or, } \quad y=1, \quad \text { or, } \quad z=1)
\end{gathered}
$$

その厳密解は次式になる.

$$
T=1-\frac{4}{3}\left[(x-0.5)^{2}+(y-0.5)^{2}+(z-0.5)^{2}\right]
$$

解析問題 2 としては, 式(24)のソース項に式(25)の基本境界条件を加えたものを取り上げて, その厳密解は式 (26)となる. 


$$
\begin{gathered}
Q=3 \pi^{2} \sin (\pi x) \sin (\pi y) \sin (\pi z) \\
T=0 \quad(x=0,1, \text { or } y=0,1, \text { or } z=0,1) \\
T=\sin (\pi x) \sin (\pi y) \sin (\pi z)
\end{gathered}
$$

解析問題 3 としては, 式(27)のソース項に式(28)の基本境界条件と式(29)の自然境界条件を加えたものを取り 上げた。

$$
\begin{gathered}
Q=\frac{6+4\left(x^{2}+y^{2}+z^{2}\right)}{e^{3}-1} e^{\left(x^{2}+y^{2}+z^{2}\right)} \\
T=\frac{e^{3}-e^{\left(1+y^{2}+z^{2}\right)}}{e^{3}-1} \quad(x=1) \\
\frac{\partial T}{\partial n}=\frac{-2 e^{\left(x^{2}+1+z^{2}\right)}}{e^{3}-1} \quad(y=1), \quad \frac{\partial T}{\partial n}=\frac{-2 e^{\left(x^{2}+y^{2}+1\right)}}{e^{3}-1} \quad(z=1), \\
\frac{\partial T}{\partial n}=0 \quad(x=0, \text { or } y=0, \text { or } z=0)
\end{gathered}
$$

その厳密解は次式になる.

$$
T=\frac{e^{3}-e^{\left(x^{2}+y^{2}+z^{2}\right)}}{e^{3}-1}
$$

解析の数值誤差指標として, 節点周りの局所メッシュ・パターンによる誤差を改善する本稿の目的に沿った 次式の最大誤差を採用した.

$$
\text { Max.Error }=\frac{\text { Max. } . T_{A i}-T_{N i} \mid}{T_{A \max }} \times 100(\%)
$$

ここで, $T_{A i}$ : 節点 $i$ での厳密解, $T_{N i}$ : 節点 $i$ での数值解, $T_{A \max }$ : 厳密解の最大值, である. 数值解析は倍精度 で行い, 要素積分は八点数值積分, 式(14)左辺から出た要素の境界積分は四点数值積分により実施し, 積分点 と点 $O$ でのソース項は式(20), (24)又は(27)により直接算出した.

図 5 に使用したメッシュを示す.その中の(a)〜 (e) と(g)のメッシュは $x y$ 平面上の四辺形メッシュを $\mathrm{z}$ 方向に等 厚み 8 層，(h)のメッシュは 16 層押し出したものであるが，(f)のメッシュは放射状のものである.“・”印で節 点位置を, 括弧内の数字で総節点数を表わす. 対称性があるため, 図 5 (a) (e)のメッシュについては, $0 \leq x \leq 0.5$, $0.5 \leq y \leq 1$ の部分のみを示し, “ $\bigcirc ”$ 印で $x=y=0.5, z=1$ の位置を示す. 図 5 (f)のメッシュについては, $0 \leq x, y, z \leq 0.5$ の部分のみを示し, “ $\bigcirc ”$ 印で $x=y=z=0.5$ の位置を示寸. 図 5 (b)のメッシュには十六個の要 素を持つ内部節点も存在し, (c) と(d)のメッシュには $\pi$ の角度を持つ平角要素も含まれ, (f)のメッシュには四つ の要素だけを持つ内部節点も存在し, 解析領域の頂点と重なる節点が三つの要素を持っている. また, 図 $5(\mathrm{~g})$ と(h)のメッシュには粗密性を持たせた. なお, メッシュ幅による収束性を検討するため, 図 5 (a) (g)のメッシ ユ（幅を $h$ と称する）とそれらのメッシュ幅を半分に縮小した同パターンの細かいメッシュ（幅をh/2 と称す る）を使って解析を実施した。この際, 図 5 (h)を(g)の細かいメッシュとして使用した.

\section{$4 \cdot 2$ 解析結果と考察}

図 6 に解析問題 1 の数值誤差を示すが, “GFE”で Galerkin 有限要素法, “CSFE” で保存型離散化での結果を 表わす。メッシュ特定のため, GFE マークの近傍に要素形状と図 5 における番号を付けた. GFE の誤差は, 立 方体要素を用いた場合にのみゼロになっているのに対して, CSFE の誤差は全てのメッシュにおいてゼロになっ 
ている. その理由は保存則の観点から解釈できる. すなわち, 式(23)の温度分布に対して，式(11)右辺により算 出した面積 $\left(-A_{1 i} L_{1 i}\right)$ を通過する熱量は, $T_{1}$ と $T_{i}$ が厳密解に等しければ, 要素形状に関係なく誤差のないものに なっている. また, 調整項の導入によりソース項の分配も保存則を厳密に満足している. その結果, 厳密解に 等しい解析結果が得られた。言い替えれば，保存型離散化の考え方の妥当性が，この解析事例により裹付けら れた.

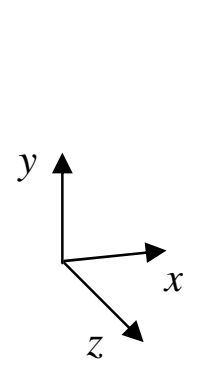

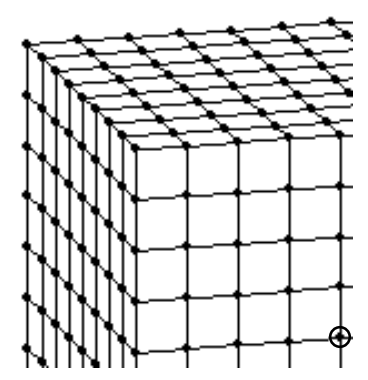

(a) Square-prism (729 Nodes, h)

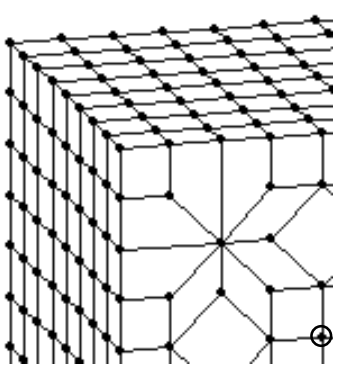

(b) $6 \rightarrow 16$ element (621 Nodes, h)

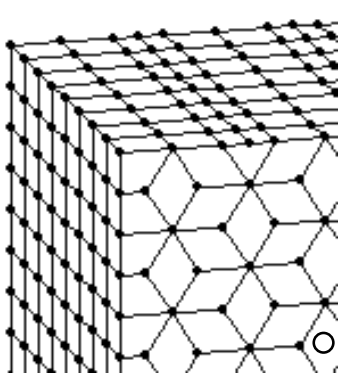

(c) Rhombus-prism

(972 Nodes, h)

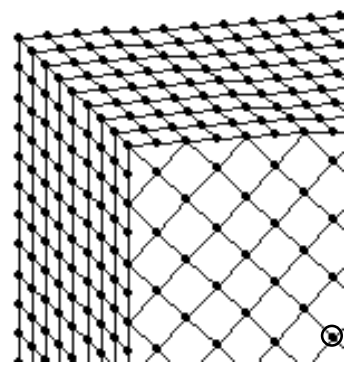

(d) Straight angle prism (1269 Nodes, h)

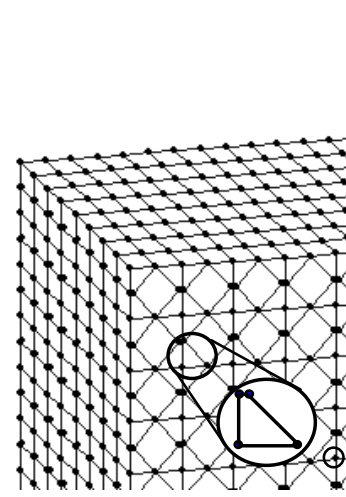

(e) Trapezium-prism

(3177 Nodes, h)

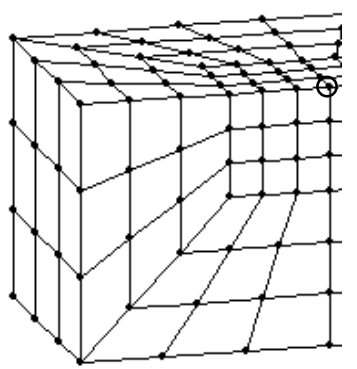

(f) Radial pattern mesh (997 Nodes, h)

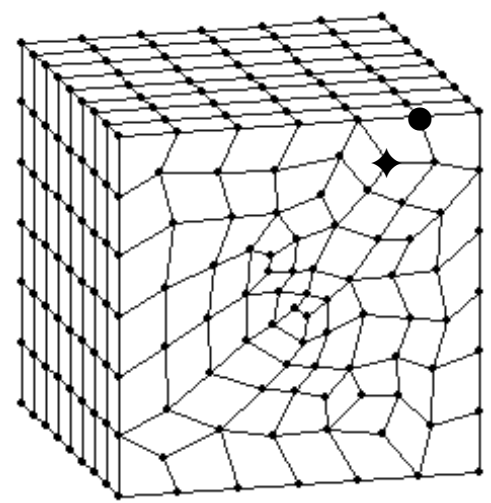

(g) Irregular quadrilateral-prism 1 (756 Nodes, h)

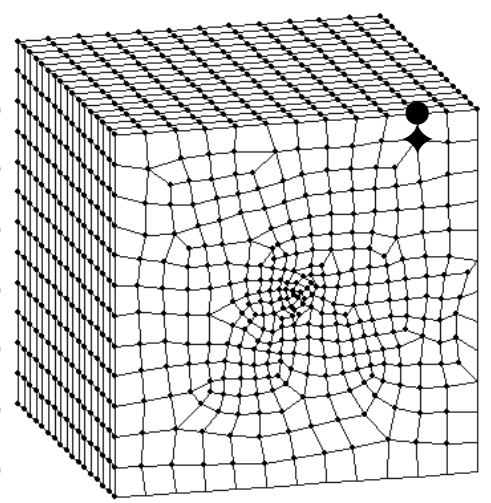

(h) Irregular quadrilateral-prism 2 (5678 Nodes, h/2)

Fig. 5 Hexahedral meshes

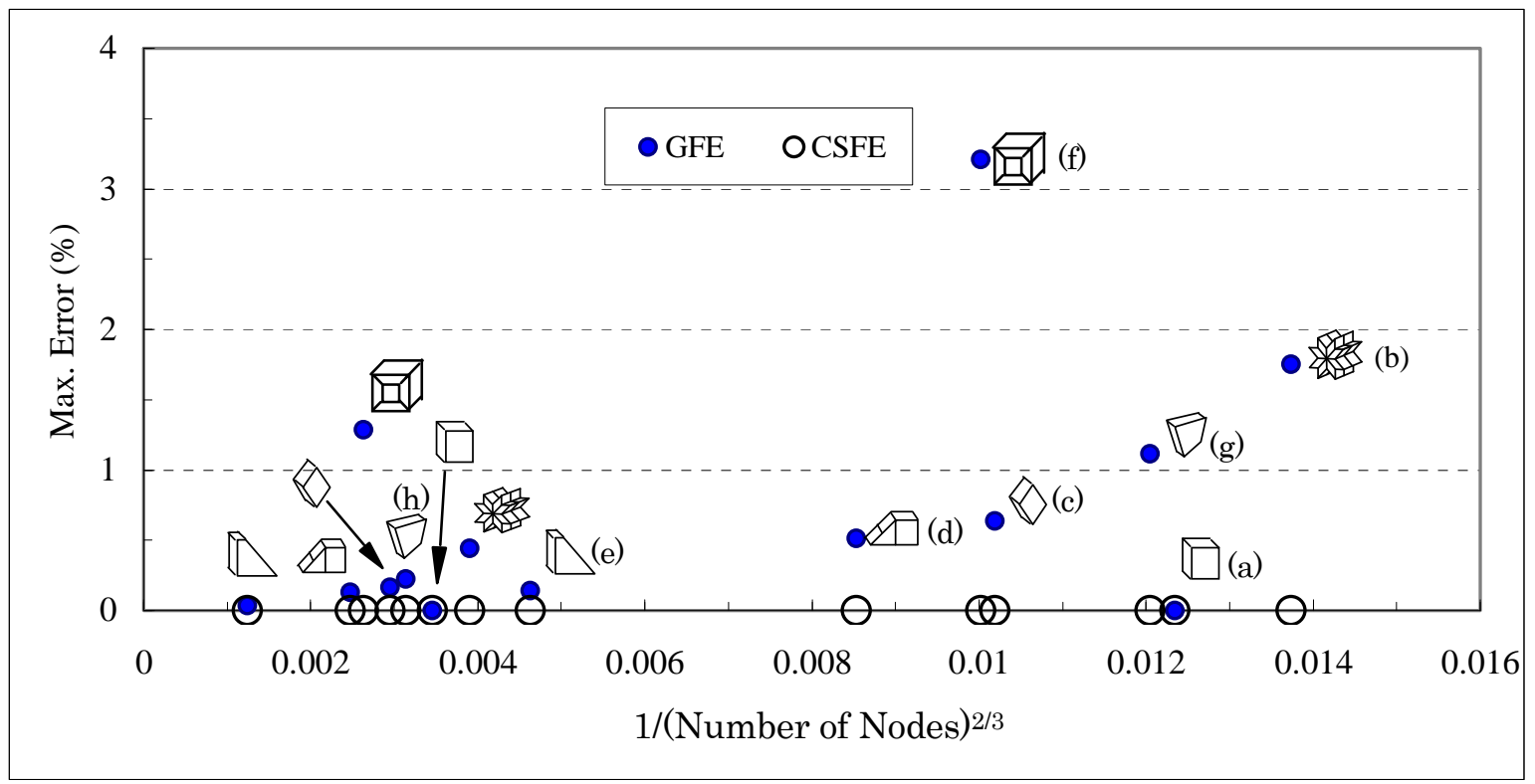

Fig. 6 Numerical error of analysis problem 1 
なお, 総節点数の $1 / 3$ 乗の逆数をメッシュ幅の平均值と見なして, 数值誤差が $O\left(h^{2}\right)$ オーダーになるため ${ }^{(1)}$, 図 6 におけるGFEの結果は右上がりの直線付近に分布すると考えられる.節点数に対して誤差が比較的に大きい メッシュは, 図 5 (b)と(f)である. メッシュ(b)における最大誤差は, 図 3 に示すような多数の低品質要素が集中 する節点に生じた。このような節点では, 図 2 (a)に示すようにVnd ${ }_{4}=V / 12$ に対して, GFEによりV/8 という 1.5 倍の体積からの発熱量が寄与されている. また, メッシュ(f)における最大誤差は, 三つの低品質要素を所有 する解析領域の頂点に生じた.

図 7 に解析問題 2 の数值誤差をメッシュ・パターンごとに示す. 各メッシュ・パターンの総節点数が異なる ため, 縦軸の目盛りは統一設定としない. 立方体メッシュでは, 式(14)における調整項がゼロになるため, 図 7 (a)に示すように両手法が同じ結果をもたらした. 同様な理由で, 基本境界条件を課した図 5 (d)のメッシュでも, ほぼ同等な誤差が得られた。 それ以外のメッシュでは, CSFEの精度改善効果が認められ, 特に図 5 (b), (c) と(f) のメッシュでは CSFE の解析精度が大幅に改善されたことが確認できる. また, メッシュ幅 $h$ とh/2での誤差を 比較すると, 誤差指標が局所的なものであるためのばらつきを考慮すれば, 両解法は共に $h^{2}$ に近い率で収束し ていくことが確認できる.

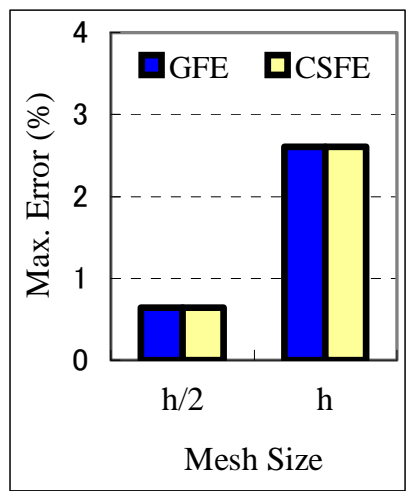

(a) Square-prism

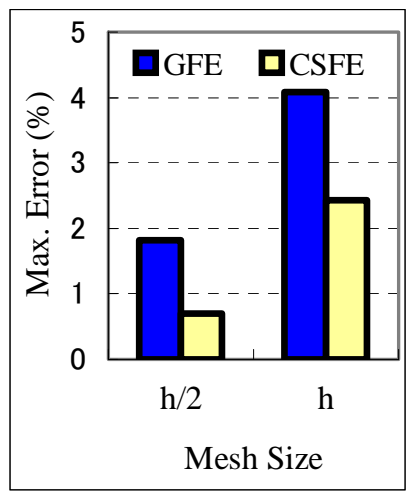

(b) $6 \rightarrow 16$ element

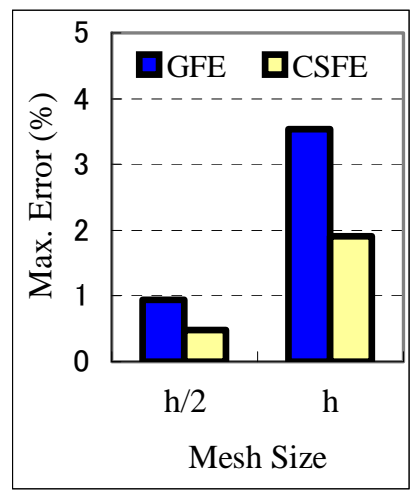

(c) Rhombus-prism

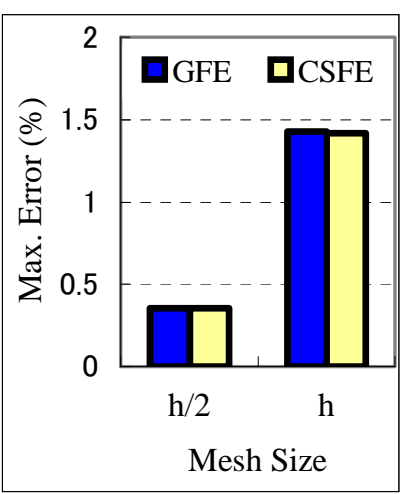

(d) Straight angle prism

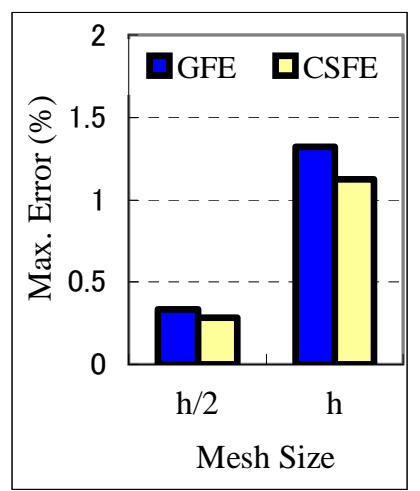

(e) Trapezium-prism

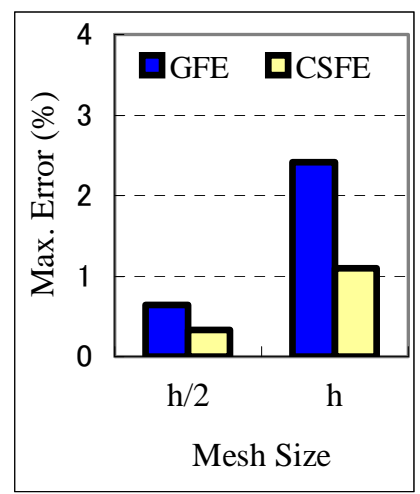

(f) Radial pattern mesh

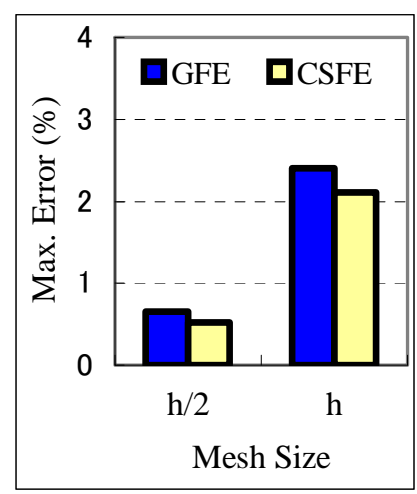

(g) Irregular quadrilateral-prism

Fig. 7 Numerical error of analysis problem 2

図 8 には解析問題 3 の数值誤差をメッシュ・パターンごとに示す. 立方体要素を使用した図 8 (a)では, 式(14) における調整項がゼロになるため, 両手法が同じ結果をもたらした. それ以外のメッシュでは, CSFE の解析䛊 差が大幅に低減され，大半のケースにおいて Galerkin 有限要素法の 2 分の 1 以下になっている.また，一例と して，不規則メッシュにおける GFE とCSFEの（最大）誤差の発生節点の $x, y$ 座標をそれぞれ“ょ”と “ の印で図 5 (g) と(h)に示す. GFEの（最大）誤差はその低減対策が講じにくい低品質な局所メッシュに生じるの に対して, CSFEの（最大）誤差は対策が比較的講じや寸い粗い局所メッシュに生じることが分かる. 収束性に ついては，ばらつきの影響を除けば，両解法は共に $h^{2} に$ 近い率で収束していくことが認められた。

六面体要素においては，ヤコビ行列の働きにより要素形状の変化に, ある程度対応してソース項を分配する 
ようになっている。にもかかわらず，本提案の改善効果が認められた．また，CSFEでの計算時間について，例 えば, 総節点数が約 23,000 のメッシュによる解析では, GFEに比べ $1 \%$ 未満の増加に止まった. また, 保存型 離散化では，メッシュ依存性が改善されたことにより，十六個や四個の要素を所有する内部節点，または，平 角などの “低品質要素”でも解析精度が保たれる。その結果，六面体メッシュに課されているトポロジーの制 約が緩和され, メッシュ分割が容易に行えるようになる. 実用解析においては, 複雑な解析領域形状で要素品 質が保証されにくい場合でのメッシュ生成コストの低減効果や，大規模で比較的粗いメッシュの使用が強いら れた場合での精度保証が期待できる.

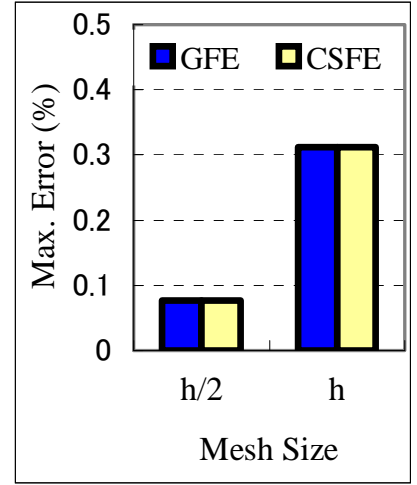

(a) Square-prism

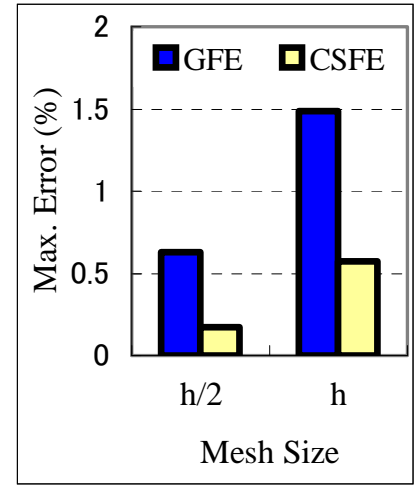

(b) $6 \rightarrow 16$ element

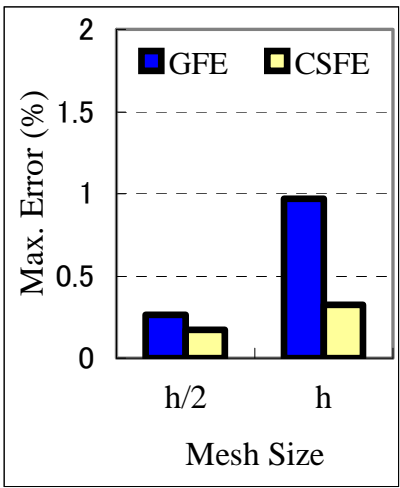

(c) Rhombus-prism

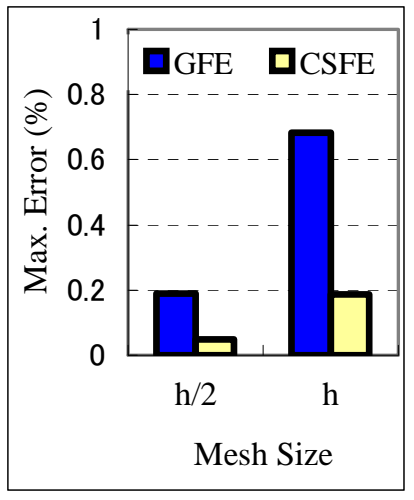

(d) Straight angle prism

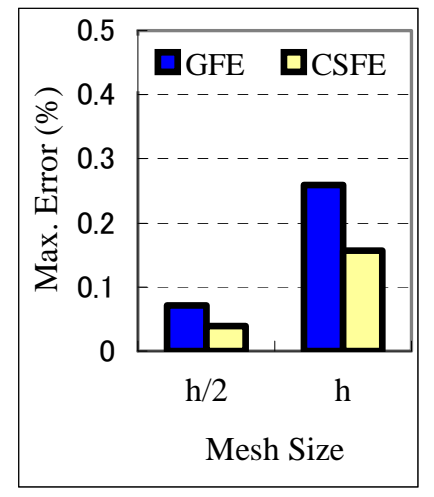

(e) Trapezium-prism

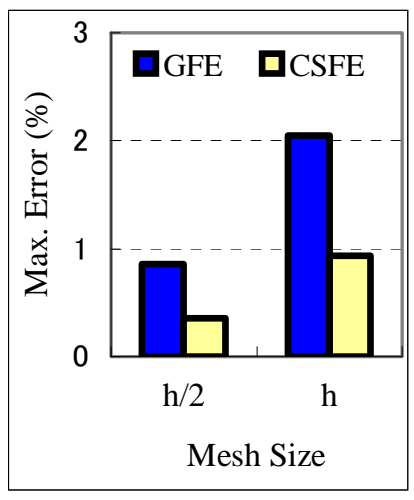

(f) Radial pattern mesh

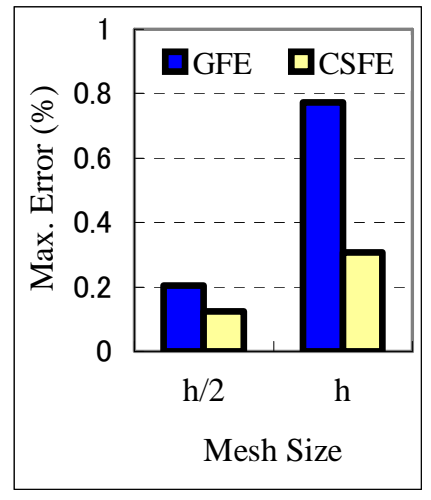

(g) Irregular quadrilateral-prism

Fig. 8 Numerical error of analysis problem 3

\section{5. 結 論}

1) 線形六面体要素を用いた Poisson の方程式の有限要素解析において, Galerkin 有限要素法の重要課題であ るメッシュ依存性問題の改善を目的とし，二次精度の流束に基づいた仮想節点領域の概念と，保存則を満たす ソース項の節点方程式への配分方法を特徵としたスキームを提案した.

2 ) 本提案では, 離散化方程式を微分方程式に収束させる効果が得られ, 要素レベルでも保存則が満たされ ていることが証明できた。任意形状の要素において正規性が満たされることは, 理論上でも興味深いものであ 万う。

3 ) 幾つかのメッシュ・パターンを用いて数值解析を行った結果, 本提案では, 従来の有限要素法のアルゴ リズムに簡単な修正を加えるだけで, しかもほぼ同じ計算量で, 低品質メッシュに対する顕著な精度改善効果

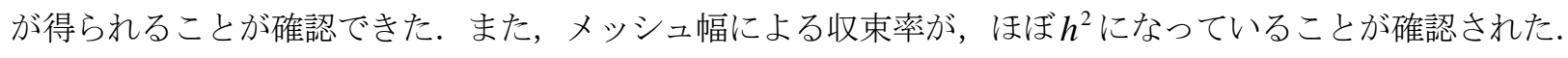

本稿をもって, 保存型離散化の三角形, 四辺形, 四面体, 六面体要素への適用体系が出来上がった. 


\section{付録 : 任意六面体要素の正規性の証明}

要素積分は, 自然座標系における $\xi=\eta=\zeta=0$ の一点積分により行う. また, $(x, y, z)$ 座標系の原点を節点 1 におき， $x_{1}=y_{1}=z_{1}=0$ とする. 証明方法としては, $V=8 J_{D}$ となるため, 仮想節点領域の合計と $J_{D}$ との関係に沿 って展開させる. $J_{D}$ は積分点でのヤコビ行列である.

配列 $D N D$ の $1,2,3$ 行目における $i(i=1,2, \ldots, 8)$ 列目の成分で, それぞれ積分点での $8 \times \partial N_{i} / \partial \xi$, $8 \times \partial N_{i} / \partial \eta, 8 \times \partial N_{i} / \partial \zeta$ を表わすと, 次式が得られる.

$$
D N D=\left[\begin{array}{rrrrrrrr}
-1 & 1 & 1 & -1 & -1 & 1 & 1 & -1 \\
-1 & -1 & 1 & 1 & -1 & -1 & 1 & 1 \\
-1 & -1 & -1 & -1 & 1 & 1 & 1 & 1
\end{array}\right]
$$

ここで， $N_{i}$ は形状関数である. ヤコビ行列 $J_{D}$ の成分は $D N D$ により表わすと次式となる.

$$
\frac{\partial u}{\partial \xi}=\frac{1}{8} \sum_{i=1}^{8} D N D_{(1, i)} u_{i}, \quad \frac{\partial u}{\partial \eta}=\frac{1}{8} \sum_{i=1}^{8} D N D_{(2, i)} u_{i}, \quad \frac{\partial u}{\partial \zeta}=\frac{1}{8} \sum_{i=1}^{8} D N D_{(3, i)} u_{i}
$$

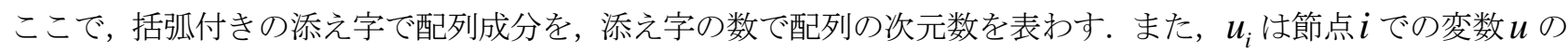
值である. $J_{D}$ を六つの項に分けた次式で表わす.

$$
\begin{array}{ll}
\frac{\partial x}{\partial \xi} \frac{\partial y}{\partial \eta} \frac{\partial z}{\partial \zeta}=\frac{1}{8^{3}} \sum_{i=2}^{8} \sum_{j=2}^{8} \sum_{k=2}^{8} A_{(i, j, k, 1)} x_{i} y_{j} z_{k}, & \frac{\partial x}{\partial \eta} \frac{\partial y}{\partial \zeta} \frac{\partial z}{\partial \xi}=\frac{1}{8^{3}} \sum_{i=2}^{8} \sum_{j=2}^{8} \sum_{k=2}^{8} A_{(i, j, k, 2)} X_{i} y_{j} z_{k}, \\
\frac{\partial x}{\partial \zeta} \frac{\partial y}{\partial \xi} \frac{\partial z}{\partial \eta}=\frac{1}{8^{3}} \sum_{i=2}^{8} \sum_{j=2}^{8} \sum_{k=2}^{8} A_{(i, j, k, 3)} x_{i} y_{j} z_{k}, & \frac{\partial x}{\partial \xi} \frac{\partial y}{\partial \zeta} \frac{\partial z}{\partial \eta}=\frac{1}{8^{3}} \sum_{i=2}^{8} \sum_{j=2}^{8} \sum_{k=2}^{8} A_{(i, j, k, 4)} x_{i} y_{j} z_{k}, \\
\frac{\partial x}{\partial \eta} \frac{\partial y}{\partial \xi} \frac{\partial z}{\partial \zeta}=\frac{1}{8^{3}} \sum_{i=2}^{8} \sum_{j=2}^{8} \sum_{k=2}^{8} A_{(i, j, k, 5)} x_{i} y_{j} z_{k}, & \frac{\partial x}{\partial \zeta} \frac{\partial y}{\partial \eta} \frac{\partial z}{\partial \xi}=\frac{1}{8^{3}} \sum_{i=2}^{8} \sum_{j=2}^{8} \sum_{k=2}^{8} A_{(i, j, k, 6)} x_{i} y_{j} z_{k}
\end{array}
$$

次式の配列を定義すると, 式(A-5)により定義された配列 $A$ が式(A-3)を満たすことが分かる.

$$
\begin{gathered}
I N C=\left[\begin{array}{cccccc}
1 & 2 & 3 & 1 & 2 & 3 \\
2 & 3 & 1 & 3 & 1 & 2 \\
3 & 1 & 2 & 2 & 3 & 1
\end{array}\right] \\
A_{(i, j, k, q)}=D N D_{(I N C(1, q), i)} \times D N D_{(I N C(2, q), j)} \times D N D_{(I N C(3, q), k)} \quad(q=1,2, \ldots, 6)
\end{gathered}
$$

次式の配列 $A A$ を定義すると, 式(A-3)より式(A-7)が得られる.

$$
\begin{gathered}
A A_{(i, j, k)}=\sum_{q=1}^{3} A_{(i, j, k, q)}-\sum_{q=4}^{6} A_{(i, j, k, q)} \\
J_{D}=\frac{1}{8^{3}} \sum_{i=2}^{8} \sum_{j=2}^{8} \sum_{k=2}^{8} A A_{(i, j, k)} X_{i} y_{j} z_{k}
\end{gathered}
$$

さらに，配列 $B$ を次式により定義すると，式(A-9)が得られる. 


$$
\begin{gathered}
B_{(i, j, k, l, m, n)}=A A_{(i, j, k)} \times A A_{(l, m, n)} \\
J_{D}{ }^{2}=\frac{1}{8^{6}} \sum_{i=2}^{8} \sum_{j=2}^{8} \sum_{k=2}^{8} \sum_{l=2}^{8} \sum_{m=2}^{8} \sum_{n=2}^{8} B_{(i, j, k, l, m, n)} X_{i} y_{j} z_{k} X_{l} y_{m} z_{n}
\end{gathered}
$$

式(A-9)における同類項については，左よりの添え字が小さいほうにまとめる. すなわち， $i 1=\min (i, l)$, $j 1=\min (j, m), k 1=\min (k, n), i 2=\max (i, l), j 2=\max (j, m), k 2=\max (k, n)$ とし, 同類項の係数を $B_{(i 1, j 1, k 1, i 2, j 2, k 2)}$ に合算させる.

なお, 形状関数の $x, y, z$ での偏微分を計算するため, 次式の行列を導入しておく.

$$
X S=\left|\begin{array}{lll}
\frac{\partial N_{s}}{\partial \xi} & \frac{\partial y}{\partial \xi} & \frac{\partial z}{\partial \xi} \\
\frac{\partial N_{s}}{\partial \eta} & \frac{\partial y}{\partial \eta} & \frac{\partial z}{\partial \eta} \\
\frac{\partial N_{s}}{\partial \zeta} & \frac{\partial y}{\partial \zeta} & \frac{\partial z}{\partial \zeta}
\end{array}\right|, \quad Y S=\left|\begin{array}{lll}
\frac{\partial x}{\partial \xi} & \frac{\partial N_{s}}{\partial \xi} & \frac{\partial z}{\partial \xi} \\
\frac{\partial x}{\partial \eta} & \frac{\partial N_{s}}{\partial \eta} & \frac{\partial z}{\partial \eta} \\
\frac{\partial x}{\partial \zeta} & \frac{\partial N_{s}}{\partial \zeta} & \frac{\partial z}{\partial \zeta}
\end{array}\right|, \quad Z S=\left|\begin{array}{lll}
\frac{\partial x}{\partial \xi} & \frac{\partial y}{\partial \xi} & \frac{\partial N_{s}}{\partial \xi} \\
\frac{\partial x}{\partial \eta} & \frac{\partial y}{\partial \eta} & \frac{\partial N_{s}}{\partial \eta} \\
\frac{\partial x}{\partial \zeta} & \frac{\partial y}{\partial \zeta} & \frac{\partial N_{s}}{\partial \zeta}
\end{array}\right| \quad(s=1,2, \ldots, 8) \quad \text { (A-10) }
$$

同様に，XT，YT，ZT で添え字 $S$ をtに書き換えた式(A-10)により定義された行列を表わす.

なお, 節点 $S$ と節点 $t$ 間の距離を $L_{s t}$ で表わすと, 式(12)と(9)より, 節点 $S$ から節点 $t$ に向かう流束が節点 $S$ にもたらす仮想節点領域は次式になることが分かる.

$$
V_{n d}=-\frac{1}{6} L_{s t}^{2} \iiint_{e}\left(\frac{\partial N_{s}}{\partial x} \frac{\partial N_{t}}{\partial x}+\frac{\partial N_{s}}{\partial y} \frac{\partial N_{t}}{\partial y}+\frac{\partial N_{s}}{\partial z} \frac{\partial N_{t}}{\partial z}\right) d x d y d z
$$

$V n d_{s t}=V n d_{t s}$ の対称性を考慮すると，八節点の仮想節点領域の合計は次式により計算でき， st の組み合わせは 式(A-13)に示された 28 通りがある.

$$
\begin{gathered}
\sum_{i=1}^{8} V n d_{i}=-\frac{8}{3 J_{D}} \sum_{s t}\left\{L_{s t}{ }^{2}[X S \times X T+Y S \times Y T+Z S \times Z T]\right\} \\
S t=(12,13,14,15,16,17,18,23,24,25,26,27,28,34,35,36,37,38, \\
45,46,47,48,56,57,58,67,68,78)
\end{gathered}
$$

式(A-12)右辺の \{\} 内のものを式(A-9) と同じ形に整理していく.まず，式(A-5)〜(A-7)の過程を参照し，XS， $X T$ と $J_{D}$ との相違点（節点の $X$ 座標が係わらないこと）に留意すると, $X S$ は式(A-14)〜(A-16), XT は式(A-17) 〜(A-19)により表わすことができる.

$$
\begin{gathered}
C_{(i, j, q)}=D N D_{(\operatorname{INC}(1, q), s)} \times D N D_{(\operatorname{INC}(2, q), i)} \times D N D_{(I N C(3, q), j)} \\
C C_{(i, j)}=\sum_{q=1}^{3} C_{(i, j, q)}-\sum_{q=4}^{6} C_{(i, j, q)} \\
X S=\frac{1}{8^{3}} \sum_{i=2}^{8} \sum_{j=2}^{8} C C_{(i, j)} y_{i} z_{j}
\end{gathered}
$$




$$
\begin{gathered}
D_{(i, j, q)}=D N D_{(I N C(1, q), t)} \times D N D_{(I N C(2, q), i)} \times D N D_{(I N C(3, q), j)} \\
D D_{(i, j)}=\sum_{q=1}^{3} D_{(i, j, q)}-\sum_{q=4}^{6} D_{(i, j, q)} \\
X T=\frac{1}{8^{3}} \sum_{i=2}^{8} \sum_{j=2}^{8} D D_{(i, j)} y_{i} z_{j}
\end{gathered}
$$

配列 $E$ を式(A-20)により定義すると，式(A-21)と(A-22)が得られる.

$$
\begin{gathered}
E_{(i, j, k, l)}=C C_{(i, j)} \times D D_{(k, l)} \\
X S \times X T=\frac{1}{8^{6}} \sum_{i=2}^{8} \sum_{j=2}^{8} \sum_{k=2}^{8} \sum_{l=2}^{8} E_{(i, j, k, l)} y_{i} z_{j} y_{k} z_{l} \\
L_{s t}{ }^{2} \times X S \times X T=\frac{1}{8^{6}} \sum_{i=2}^{8} \sum_{j=2}^{8} \sum_{k=2}^{8} \sum_{l=2}^{8} E_{(i, j, k, l)}\left(x_{s} y_{i} z_{j} x_{s} y_{k} z_{l}-2 x_{s} y_{i} z_{j} x_{t} y_{k} z_{l}+x_{t} y_{i} z_{j} x_{t} y_{k} z_{l}\right. \\
+y_{s} y_{s} y_{i} z_{j} y_{k} z_{l}-2 y_{s} y_{t} y_{i} z_{j} y_{k} z_{l}+y_{t} y_{t} y_{i} z_{j} y_{k} z_{l} \\
\left.+z_{s} z_{s} y_{i} z_{j} y_{k} z_{l}-2 z_{s} z_{t} y_{i} z_{j} y_{k} z_{l}+z_{t} z_{t} y_{i} z_{j} y_{k} z_{l}\right)
\end{gathered}
$$

さらに， $E_{(i, j, k, l)}$ を式(A-22)の右辺( )内の各係数に掛けたものを配列 $X Y Z ， Y Y Z$ と ZYZ の成分とすると, 式(A-22)を次式 に書き換えることができる.

$$
\begin{aligned}
& L_{s t}{ }^{2} \times X S \times X T \\
& =\frac{1}{8^{6}} \sum_{i=2}^{8} \sum_{j=2}^{8} \sum_{k=2}^{8} \sum_{l=2}^{8}\left(X Y Z_{(s, i, j, s, k, l)} X_{s} y_{i} Z_{j} X_{s} y_{k} Z_{l}+X Y Z_{(s, i, j, t, k, l)} X_{s} y_{i} Z_{j} X_{t} y_{k} Z_{l}+X Y Z_{(t, i, j, t, k, l)} X_{t} y_{i} Z_{j} X_{t} y_{k} Z_{l}\right. \\
& +Y Y Z_{(s, s, i, j, k, l)} y_{s} y_{s} y_{i} z_{j} y_{k} z_{l}+Y Y Z_{(s, t, i, j, k, l)} y_{s} y_{t} y_{i} z_{j} y_{k} z_{l}+Y Y Z_{(t, t, i, j, k, l)} y_{t} y_{t} y_{i} z_{j} y_{k} z_{l} \\
& \left.+Z Y Z_{(s, s, i, j, k, l)} Z_{s} Z_{s} y_{i} Z_{j} y_{k} Z_{l}+Z Y Z_{(s, t, i, j, k, l)} Z_{s} Z_{t} y_{i} Z_{j} y_{k} Z_{l}+Z Y Z_{(t, t, i, j, k, l)} Z_{t} Z_{t} y_{i} Z_{j} y_{k} Z_{l}\right)
\end{aligned}
$$

ここで,

$$
\begin{array}{lll}
X Y Z_{(s, i, j, s, k, l)}=E_{(i, j, k, l)}, & X Y Z_{(s, i, j, t, k, l)}=-2 E_{(i, j, k, l)}, & X Y Z_{(t, i, j, t, k, l)}=E_{(i, j, k, l)} \\
Y Y Z_{(s, s, i, j, k, l)}=E_{(i, j, k, l)}, & Y Y Z_{(s, t, i, j, k, l)}=-2 E_{(i, j, k, l)}, & Y Y Z_{(t, t, i, j, k, l)}=E_{(i, j, k, l)}, \\
Z Y Z_{(s, s, i, j, k, l)}=E_{(i, j, k, l)}, & Z Y Z_{(s, t, i, j, k, l)}=-2 E_{(i, j, k, l)}, & Z Y Z_{(t, t, i, j, k, l)}=E_{(i, j, k, l)}
\end{array}
$$

である.この際，Eから值を渡されていない $X Y Z ， Y Y Z$ と ZYZ の成分は，ゼロのままである.

同様に, YS とYT が節点の $y$ 座標に係わらないことに留意すると, 式(A-12)の右辺\{\}内の 2 項目は式(A-26) (A-28) により表わすことができる. ただし，E は式(A-20)，CC は式(A-15)，C は式(A-29)，DD は式(A-18)，D は式(A-30)，に より算出するものである. 


$$
\begin{aligned}
& L_{s t}{ }^{2} \times Y S \times Y T \\
& =\frac{1}{8^{3}} \sum_{i=2}^{8} \sum_{j=2}^{8} \sum_{k=2}^{8} \sum_{l=2}^{8}\left(X X Z_{(s, s, i, j, k, l)} X_{s} X_{s} X_{i} Z_{j} X_{k} Z_{l}+X X Z_{(s, t, i, j, k, l)} X_{s} X_{t} X_{i} Z_{j} X_{k} Z_{l}+X X Z_{(t, t, i, j, k, l)} X_{t} X_{t} X_{i} Z_{j} X_{k} Z_{l}\right. \\
& +X Y Z_{(i, s, j, k, s, l)} x_{i} y_{s} z_{j} x_{k} y_{s} z_{l}+X Y Z_{(i, s, j, k, t, l)} x_{i} y_{s} z_{j} x_{k} y_{t} z_{l}+X Y Z_{(i, t, j, k, t, l)} X_{i} y_{t} z_{j} x_{k} y_{t} z_{l} \\
& \left.+Z X Z_{(s, s, i, j, k, l)} Z_{s} Z_{s} X_{i} Z_{j} X_{k} Z_{l}+Z X Z_{(s, t, i, j, k, l)} Z_{s} Z_{t} X_{i} Z_{j} X_{k} Z_{l}+Z X Z_{(t, t, i, j, k, l)} Z_{t} Z_{t} X_{i} Z_{j} X_{k} Z_{l}\right) \\
& X Y Z_{(i, s, j, k, s, l)}=E_{(i, j, k, l)}, \quad X Y Z_{(i, s, j, k, t, l)}=-2 E_{(i, j, k, l)}, \quad X Y Z_{(i, t, j, k, t, l)}=E_{(i, j, k, l)} \\
& X X Z_{(s, s, i, j, k, l)}=E_{(i, j, k, l)}, \quad X X Z_{(s, t, i, j, k, l)}=-2 E_{(i, j, k, l)}, \quad X X Z_{(t, t, i, j, k, l)}=E_{(i, j, k, l)}, \\
& Z X Z_{(s, s, i, j, k, l)}=E_{(i, j, k, l)}, \quad Z X Z_{(s, t, i, j, k, l)}=-2 E_{(i, j, k, l)}, \quad Z X Z_{(t, t, i, j, k, l)}=E_{(i, j, k, l)} \\
& C_{(i, j, q)}=D N D_{(I N C(1, q), i)} \times D N D_{(I N C(2, q), s)} \times D N D_{(I N C(3, q), j)} \\
& D_{(i, j, q)}=D N D_{(\operatorname{INC}(1, q), i)} \times D N D_{(\operatorname{INC}(2, q), t)} \times D N D_{(\operatorname{INC}(3, q), j)}
\end{aligned}
$$

同様に，式(A-12)の右辺\{\}内の3項目は，式(A-31)〜(A-35)，(A-20)，(A-15)と(A-18)により表わすことができる.

$$
\begin{aligned}
& L_{s t}^{2} \times Z S \times Z T \\
& =\frac{1}{8^{6}} \sum_{i=2}^{8} \sum_{j=2}^{8} \sum_{k=2}^{8} \sum_{l=2}^{8}\left(X X Y_{(s, s, i, j, k, l)} X_{s} x_{s} x_{i} y_{j} x_{k} y_{l}+X X Y_{(s, t, i, j, k, l)} X_{s} x_{t} x_{i} y_{j} x_{k} y_{l}+X X Y_{(t, t, i, j, k, l)} X_{t} x_{t} x_{i} y_{j} x_{k} y_{l}\right. \\
& +Y X Y_{(s, s, i, j, k, l)} y_{s} y_{s} x_{i} y_{j} x_{k} y_{l}+Y X Y_{(s, t, i, j, k, l)} y_{s} y_{t} x_{i} y_{j} x_{k} y_{l}+Y X Y_{(t, t, i, j, k, l)} y_{t} y_{t} x_{i} y_{j} x_{k} y_{l} \\
& \left.+X Y Z_{(i, j, s, k, l, s)} x_{i} y_{j} z_{s} x_{k} y_{l} z_{s}+X Y Z_{(i, j, s, k, l, t)} X_{i} y_{j} z_{s} x_{k} y_{l} z_{t}+X Y Z_{(i, j, t, k, l, t)} X_{i} y_{j} z_{t} x_{k} y_{l} z_{t}\right) \\
& X Y Z_{(i, j, s, k, l, s)}=E_{(i, j, k, l)}, \quad X Y Z_{(i, j, s, k, l, t)}=-2 E_{(i, j, k, l)}, \quad X Y Z_{(i, j, t, k, l, t)}=E_{(i, j, k, l)} \\
& X X Y_{(s, s, i, j, k, l)}=E_{(i, j, k, l)}, \quad X X Y_{(s, t, i, j, k, l)}=-2 E_{(i, j, k, l)}, \quad X X Y_{(t, t, i, j, k, l)}=E_{(i, j, k, l)}, \\
& Y X Y_{(s, s, i, j, k, l)}=E_{(i, j, k, l)}, \quad Y X Y_{(s, t, i, j, k, l)}=-2 E_{(i, j, k, l)}, \quad Y X Y_{(t, t, i, j, k, l)}=E_{(i, j, k, l)} \\
& C_{(i, j, q)}=D N D_{(I N C(1, q), i)} \times D N D_{(I N C(2, q), j)} \times D N D_{(I N C(3, q), s)} \\
& D_{(i, j, q)}=D N D_{(\operatorname{INC}(1, q), i)} \times D N D_{(\operatorname{INC}(2, q), j)} \times D N D_{(\operatorname{INC}(3, q), t)}
\end{aligned}
$$

式(A-23)，(A-26)と(A-31)を式(A-12)に代入すると，仮想節点領域の合計は，足し算後の配列を用いた次式により表わすこ とができる.

$$
\sum_{i=1}^{8} \operatorname{Vnd}_{i}=-\frac{8}{3 J_{D}} \times \frac{1}{8^{6}} \sum_{i=2}^{8} \sum_{j=2}^{8} \sum_{k=2}^{8} \sum_{l=2}^{8} \sum_{m=2}^{8} \sum_{n=2}^{8}\left(X Y Z_{(i, j, k, l, m, n)} X_{i} y_{j} z_{k} x_{l} y_{m} z_{n}\right.
$$




$$
\begin{aligned}
& +Y Y Z_{(i, j, k, l, m, n)} y_{i} y_{j} y_{k} z_{l} y_{m} z_{n}+Z Y Z_{(i, j, k, l, m, n)} z_{i} z_{j} y_{k} z_{l} y_{m} z_{n}+X X Z_{(i, j, k, l, m, n)} X_{i} X_{j} x_{k} z_{l} x_{m} z_{n} \\
& \left.+Z X Z_{(i, j, k, l, m, n)} Z_{i} z_{j} x_{k} z_{l} x_{m} z_{n}+X X Y_{(i, j, k, l, m, n)} X_{i} x_{j} x_{k} y_{l} x_{m} y_{n}+Y X Y_{(i, j, k, l, m, n)} y_{i} y_{j} x_{k} y_{l} x_{m} y_{n}\right)
\end{aligned}
$$

同類項のまとめは, $X Y Z$ については $B$ と同じ方法で行う. $Y Y Z, X X Z$ と $X X Y$ については, 添え字が(i1,i2,i3, $j 1$, $i 4, j 2)$ の項にまとめ, $(i 1 \leq i 2 \leq i 3 \leq i 4, j 1 \leq j 2)$ とする. ZYZ $Z X Z$ とYXY については, 添え字が(i1,i2, j1,i3, $j 2, i 4)$ の項にまとめ, $(i 1 \leq i 2 \leq i 3 \leq i 4, j 1 \leq j 2)$ とする.

最後に,

$$
\begin{gathered}
X Y Z_{(i, j, k, l, m, n)}=-3 \times B_{(i, j, k, l, m, n)} \quad(i, j, k, l, m, n=2,3, \ldots, 8) \\
Y Y Z_{(i, j, k, l, m, n)}=0, \quad Z Y Z_{(i, j, k, l, m, n)}=0, \quad X X Z_{(i, j, k, l, m, n)}=0, \\
Z X Z_{(i, j, k, l, m, n)}=0, \quad X X Y_{(i, j, k, l, m, n)}=0, \quad Y X Y_{(i, j, k, l, m, n)}=0 \quad(i, j, k, l, m, n=2,3, \ldots, 8)
\end{gathered}
$$

となっていることが確認できると, 式(A-9)より式(A-36)の右辺は8 $J_{D}$ になっていることが分かり，V=8J $J_{D}$ となってるた め式(17)の証明は完了である.

式(A-37)と(A-38)は成立することが FORTRAN77 のプログラムにより確認された.

\section{文献}

(1) Zienkiewicz, O.C. and Taylor, R.L.原著, 矢川元基ら訳, マトリックス有限要素法, 改訂新版(1996), pp. 2667-269, 科学技術出版社.

(2) Chung, T.J., Finite Element Analysis in Fluid Dynamics(1978), McGraw-Hill International Book Company.

(3) 菊地文雄, 有限要素法概説, 新訂版(1999), pp. 137-143, サイエンス社.

(4) Emery, A.F. and Carson, W.W., "An Evaluation of the Use of the Finite-Element Method in the Computation of Temperature", Transactions of the ASME, Journal of Heat Transfer, May(1971), pp. 136-145.

(5) Kurtze, D.A., "Failures of Local Approximation in Finite-Element Methods", International Journal for Numerical Methods in Engineering, Vol. 23(1986), pp. 1483-1494.

(6) Abboud, J.B. and Hardisty, H., "Control-Volume Energy-Balance FE Formulation of the 8-Node Hexahedron element", Communications in Applied Numerical Methods, Vol. 7(1991), pp. 141-153.

(7) Taylor, G.A., Bailey, C. and Cross, M., "A Vertex-Based Finite Volume Method Applied to Non-Linear Material Problems in Computational Solid Mechanics”, International Journal for Numerical Methods in Engineering, Vol. 56(2003), pp. 507-529.

(8) Iwaki, T., "Comparison of FEM and Triangular FDM in Heat Conduction Problems", Theoretical and Applied Mechanics, Vol. 23(1975), p. 279.

(9) Urata, N., "Fluid Analysis in Chemical Engineering”, Preprint, 1978.

(10)Kanayama, H., “Discrete Models for Salinity Distribution in a Bay: Conservation Laws and Maximum Principle”, Theoretical and Applied Mechanics, Vol. 28(1980), pp. 559-579.

(11)邵 長城, 飯沼敏也, “有限要素解析におけるソース項の保存型離散化（三角形要素の場合）”, 日本計算工学会 論文集，No.20110008(2011).

(12)邵 長城, 飯沼敏也, “有限要素解析におけるソース項の保存型離散化（四辺形要素の場合）”, 日本機械学会論 文集 B 編，Vol. 77, No. 783(2011), pp. 2117-2132.

(13)邵 長城, 飯沼敏也, “有限要素解析におけるソース項の保存型離散化（四面体要素の場合）”，日本機械学会論 文集 B 編，Vol. 78, No. 786(2012), pp. 311-327. 